\title{
Uptake and Partitioning of Nutrients in Blackberry and Raspberry and Evaluating Plant Nutrient Status for Accurate Assessment of Fertilizer Requirements
}

\author{
Bernadine C. Strik ${ }^{1,3}$ and David R. Bryla ${ }^{2}$
}

ADDITIONAL INDEX WORDs. Rubus, nitrogen, leaf tissue analysis, nutrient removal, organic, fertilization

SUMMARY. Raspberry and blackberry (Rubus sp.) plantings have a relatively low nutrient requirement compared with many other perennial fruit crops. Knowledge of annual accumulation of nutrients and periods of rapid uptake allows for better management of fertilization programs. Annual total nitrogen (N) accumulation in the aboveground plant ranged from 62 to 110 and 33 to $39 \mathrm{lb} /$ acre in field-grown red raspberry $(R u b u s$ idaeus) and blackberry (Rubus ssp. rubus), respectively. Research on the fate of applied ${ }^{15} \mathrm{~N}$ (a naturally occurring istope of $\mathrm{N}$ ) has shown that primocanes rely primarily on fertilizer $\mathbf{N}$ for growth, whereas floricane growth is highly dependent on stored $\mathbf{N}$ in the over-wintering primocanes, crown, and roots; from $30 \%$ to $40 \%$ of stored $\mathrm{N}$ was allocated to new growth. Plants receiving higher rates of $\mathbf{N}$ fertilizer took up more $\mathrm{N}$, often leading to higher $\mathrm{N}$ concentrations in the tissues, including the fruit. Reallocation of $\mathrm{N}$ from senescing floricanes and primocane leaves to canes, crown, and roots has been documented. Accumulation of other macro- and micronutrients in plant parts usually preceded growth. Primocanes generally contained the highest concentration of most nutrients during the growing season, except calcium $(\mathrm{Ca})$, copper $(\mathrm{Cu})$, and zinc $(\mathrm{Zn})$, which often were more concentrated in roots. Roots typically contained the highest concentration of all nutrients during winter dormancy. Nutrient partitioning varied considerably among elements due to different nutrient concentrations and requirements in each raspberry and blackberry plant part. This difference not only affected the proportion of each nutrient allocated to plant parts, but also the relative amount of each nutrient lost or removed during harvest, leaf senescence, and pruning. Macro- and micronutrient concentrations are similar for raspberry and blackberry fruit, resulting in a similar quantity of nutrient removed with each ton of fruit at harvest; however, yield may differ among cultivars and production systems. Nutrient removal in harvested red raspberry and blackberry fruit ranged from 11 to $18 \mathrm{lb} /$ acre $\mathrm{N}, 10$ to $19 \mathrm{lb} /$ acre potassium (K), 2 to $4 \mathrm{lb}$ /acre phosphorus (P), 1 to $2 \mathrm{lb} /$ acre $\mathrm{Ca}$, and 1 to $4 \mathrm{lb} /$ acre magnesium $(\mathrm{Mg})$. Pruning senescing floricanes in August led to greater plant nutrient losses than pruning in autumn. Primocane leaf nutrient status is often used in nutrient management programs. Leaf nutrient concentrations differ with primocane leaf sampling time and cultivar. In Oregon, the present recommended sampling time of late July to early August is acceptable for floricane-fruiting raspberry and blackberry types, and primocane-fruiting raspberry, but not for primocane-fruiting blackberry, where sampling leaves on primocane branches during the green fruit stage is recommended. Presently published leaf tissue standards appear to be too high for $\mathrm{K}$ in primocanefruiting raspberry and blackberry, which is not surprising since the primocanes are producing fruit at the time of sampling and fruit contain a substantial amount of $K$.

$\mathrm{C}$ aneberries (raspberry and blackberry) are important crops in the United States with a reported 11,900 acres of blackberry in 2005 (Strik et al., 2007) and 16,400 and 1650 acres of red and black raspberry in 2014, respectively [U.S. Department of Agriculture (USDA), 2015]. There were also 495 and 663 acres of organic blackberry and raspberry, respectively, in the United States in 2008 (USDA, 2010).

Caneberry plants are perennial with an expected life span of 5 to 15 years for raspberry and 25 to 40 years for blackberry, depending on the cultivar, the incidence of pests and diseases, and the production region. Individual canes are annual or biennial, depending on the type of caneberry and the production system used. In biennial-fruiting or "summer-bearing" raspberry and blackberry, normal flowering requires cessation of growth, bud dormancy, and sufficient chilling. The canes, in this case, are vegetative during the first year of growth (primocanes) and flower, fruit, and then senesce in the second year (floricanes). Primocaneor annual-fruiting raspberry and blackberry cultivars are different from floricane-fruiting cultivars, as they have no low temperature requirement for flower bud initiation (Strik, 2012). Annual-fruiting cultivars produce fruit on the tip portion of the primocane in late summer through autumn. The portion of the cane that fruited then senesces. The base of this cane may be left in the field after pruning in winter and allowed to fruit in early summer of the second year (floricane). This is called "double-cropping." Primocanes and floricanes exist together on mature biennial-fruiting plants and on doublecropped, primocane-fruiting plants. This unique growth habit makes nutrient management of caneberry plants somewhat of a challenge, as nutrients are both accumulated (in primocanes, roots, and a basal crown) and lost (in fruit, floricanes, and senesced leaves) from the plants simultaneously.

There are three classifications of blackberry cultivars, based on the cane architecture, including trailing (e.g., Marion and Obsidian), erect (e.g., Navaho and Ouachita), and semierect (e.g., Chester Thornless and Triple Crown) cultivars. The three types ripen at different times of the season and require different pruning methods. Trailing and semierect types are biennial fruiting, whereas the erect types can be biennial or annual fruiting (Strik and Finn, 2012).

Commercial caneberry growers are encouraged to develop fertilization programs based on initial nitrogen recommendations (which depend on caneberry type and planting age), with adjustments made to $\mathrm{N}$ and other nutrients as needed, based on periodic soil nutrient analysis and annual leaf tissue analysis. Primocane leaf nutrient status, as compared with sufficiency levels published in currently available nutrient management guides (Bolda et al., 2012; Bushway et al., 2008; Hart et al., 2006), coupled with observations of plant growth and yield are presently used to develop or modify nutrient management programs. The recommended nutrient sufficiency levels are similar among these guides and all have the same standards, regardless of caneberry type.

In this paper, we review and present information on fertilizer rate and source studies, $\mathrm{N}$ uptake and 
implications for timing of fertilizer $\mathrm{N}$, accumulation and loss of nutrients, and leaf nutrient concentrations throughout the season among the different types of caneberry.

\section{Fertilizer source and rate}

Macro- and micronutrient recommendations are often based on published research studies and grower experience. Recommended rates of $\mathrm{N}$ to apply to red raspberry depend on raspberry type and production region. For example, in eastern United States, $\mathrm{N}$ recommendations range from 25 to $55 \mathrm{lb} /$ acre in new plantings, 40 to 80 $\mathrm{lb} /$ acre in mature, summer-bearing plantings, and 70 to $100 \mathrm{lb} /$ acre in mature, primocane-fruiting plantings (Bushway et al., 2008; Krewer et al., 1999). In Oregon, the recommendation is to apply 30 to $50 \mathrm{lb} /$ acre $\mathrm{N}$ during the establishment year and 50 to $80 \mathrm{lb} /$ acre in subsequent years, plus an additional $20 \mathrm{lb} /$ acre applied at bloom to primocane-fruiting types (Hart et al., 2006). In California, N rates of $10 \mathrm{lb} /$ acre per month from February until harvest ends for first year fields of primocane-fruiting cultivars and first year and older floricane-fruiting raspberry are recommended (Bolda et al., 2012). In second year and older primocane-fruiting raspberry, they recommend applications of $20 \mathrm{lb} /$ acre N per month during this same period. For black raspberry (Rubus occidentalis), $\mathrm{N}$ rates of 20 to $40 \mathrm{lb} / \mathrm{acre}$ and 40 to $60 \mathrm{lb} /$ acre are recommended for the establishment and subsequent years, respectively (Hart et al., 2006). Recommendations for blackberry also depend on planting age and the type grown, with 25 to 50 $\mathrm{lb} /$ acre $\mathrm{N}$ in the establishment year and 50 to $80 \mathrm{lb} /$ acre being common ranges (Fernandez and Ballington, 1999; Hart et al., 2006; Krewer et al., 1999; Kuepper et al., 2003).

This paper was part of the colloquium "Recent Advances in Perennial Berry Crop Nutrition and Directions for Future Research" held 28 July 2014 at the ASHS Annual Conference, Orlando, FL and sponsored by the Viticulture and Small Fruit (VSF) Working Group. We appreciate the contributions of graduate students Paula Mohadjer, Hannah Rempel, Renee Harkins, Javier Fernandez-Salvador, and Emily Dixon.

${ }^{1}$ Department of Horticulture, Agricultural and Life Science Building 4017, Oregon State University, Corvallis, OR 97331

${ }^{2}$ U.S. Department of Agriculture, Agricultural Research Service, 3420 NW Orchard Avenue, Corvallis, OR 97330

${ }^{3}$ Corresponding author. E-mail: bernadine.strik@ oregonstate.edu.
Reviews of $\mathrm{N}$ research in caneberries were done by Dale (1989) and Strik (2008). In blackberry, the impact of $\mathrm{N}$ fertilization rate on yield varies among the types and cultivars, growing regions, and probably the soil type (Archbold et al., 1989; Chaplin and Martin, 1980; Dale, 1989; DeGomez et al., 1986; Heiberg, 2002; Kowalenko, 1994b; Kowalenko et al., 2000; Lawson and Waister, 1972; Lockshin and Elfving, 1981; Mohadjer et al., 2001 ; Naraguma and Clark, 1998; Nelson and Martin, 1986; Papp et al., 1984; Rempel et al., 2004; Rincon and Salas, 1987; Smolarz et al., 1982; Spiers, 1993). In biennialfruiting types, $\mathrm{N}$ application in one season may affect both the current yield of the floricanes, mainly through increased fruit size, and the next season's yield, through its impact on primocane growth and flower bud development (e.g., Lawson and Waister, 1972). In annual-fruiting types, $\mathrm{N}$ application may increase primocane number and advance growth and flowering, thus increasing yield (Buskiene and Uselis, 2008; DeGomez et al., 1986; Lockshin and Elfving, 1981).

Effects of $\mathrm{N}$ fertilization rate on fruit quality of caneberry crops have varied with little effect in 'Thornless Evergreen' (Nelson and Martin, 1986) and 'Arapaho' (Alleyne and Clark, 1997) blackberry. In a 5-year study, Papp et al. (1984) found that $\mathrm{N}$ fertilization decreased total soluble solids of red raspberry fruit.

The availability of fertilizer $\mathrm{N}$ depends on the fertilizer source (Gutser et al., 2005) and the method of application (Kowalenko et al., 2000). Soil pH affects nitrification, with ammonium-N sources converted more rapidly to nitrate- $\mathrm{N}$ at a $\mathrm{pH}$ of 6.0 than at 5.5 (Hart et al., 2006). The recommended soil $\mathrm{pH}$ for caneberries is 5.6 to 6.5 (Bushway et al., 2008; Hart et al., 2006). Current nutrient recommendations are to apply primarily the nitrate form of $\mathrm{N}$ (Bushway et al., 2008; Hart et al., 2006). However, raspberry has a similar rate of biomass production when fertilized with nitrate or ammonium forms of $\mathrm{N}$ (Claussen and Lenz, 1999). The response of caneberry plants to soil $\mathrm{pH}$ also likely depends on the availability of other macro- and micronutrients.

The most common $\mathrm{N}$ fertilizers applied to caneberry are calcium nitrate, urea, and ammonium sulfate in conventional systems and Organic Materials Review Institute (OMRI)-listed fish emulsion, pelletized chicken litter, soybean (Glycine max) meal, or feather meal in organic systems. In studies of certified organic blackberry, three cultivars responded similarly to equivalent rates of $\mathrm{N}$ applied through various sources, including fish emulsion as a liquid soil drench, pelletized chicken litter, and soybean meal when applied to the in-row area in split applications (Fernandez-Salvador et al., 2015b). Two cultivars also responded similarly to a blend of corn (Zea mays) steep liquor and fish waste digestion and a blend of fish solubles and molasses, when either blend was diluted and applied through the drip irrigation system (Fernandez-Salvador et al., 2015a). Organic fertilizer sources often differ in $\mathrm{N}$ release rate, which is an important factor to consider when targeting the crop needs (Gutser et al., 2005), soil N availability (Gale et al., 2006), and the cost (per pound of $\mathrm{N}$ applied) of the fertilizer (FernandezSalvador et al., 2015b).

Many nutrients other than $\mathrm{N}$ are present in organic fertilizers and are thus applied to the planting, whether required or not (Fernandez-Salvador et al., 2015a; Harkins et al., 2014; Larco et al., 2013). Fertilization with different sources of organic fertilizers, or various rates of $\mathrm{N}$ when using inorganic sources, may affect the con-

\begin{tabular}{|c|c|c|c|}
\hline \multicolumn{4}{|l|}{ Units } \\
\hline $\begin{array}{l}\text { To convert U.S. to } \\
\text { SI, multiply by }\end{array}$ & U.S. unit & SI unit & $\begin{array}{l}\text { To convert SI to } \\
\text { U.S., multiply by }\end{array}$ \\
\hline 0.4047 & $\operatorname{acre}(s)$ & ha & 2.4711 \\
\hline 0.3048 & $\mathrm{ft}$ & $\mathrm{m}$ & 3.2808 \\
\hline 2.54 & inch(es) & $\mathrm{cm}$ & 0.3937 \\
\hline 0.4536 & $\mathrm{lb}$ & $\mathrm{kg}$ & 2.2046 \\
\hline 1.1209 & $\mathrm{lb} / \mathrm{acre}$ & $\mathrm{kg} \cdot \mathrm{ha}^{-1}$ & 0.8922 \\
\hline 0.5000 & $\mathrm{lb} /$ ton & $\mathrm{kg} \cdot \mathrm{Mg}^{-1}$ & 2.0000 \\
\hline 70.0532 & $\mathrm{oz} /$ acre & $\mathrm{g} \cdot \mathrm{ha} \mathrm{a}^{-\mathrm{o}}$ & 0.0143 \\
\hline 31.2500 & $\mathrm{oz} / \mathrm{ton}$ & $\mathrm{g} \cdot \mathrm{Mg}^{-1}$ & 0.0320 \\
\hline 1 & ppm & $\mathrm{mg} \cdot \mathrm{kg}^{-1}$ & 1 \\
\hline 2.2417 & $\operatorname{ton}(\mathrm{s}) /$ acre & $\mathrm{Mg} \cdot \mathrm{ha}^{-1}$ & 0.4461 \\
\hline
\end{tabular}


centration of other macroand micronutrients in the plants (e.g., Chaplin and Martin, 1980; Fernandez-Salvador et al., 2015a, 2015b; Harkins et al., 2014; Naraguma and Clark, 1998; Spiers and Braswell, 2002).

Generally, increased rates of macronutrient fertilization led to increased leaf levels of the corresponding nutrient in blackberry (Spiers, 1993; Spiers and Braswell, 2002). However, Nelson and Martin (1986) found no relationship between increased rates of $\mathrm{K}$ fertilization and leaf $\mathrm{K}$ in blackberry. Application of boron (B) as a foliar to red raspberry reduced yield in 1 of 4 years (Chaplin and Martin, 1980).

\section{Nitrogen uptake}

Fertilizer rate studies do not clearly determine the fate of the fertilizer in the plant or soil, or how the nutrient is partitioned within the plant. Nitrogen-cycling patterns have been studied in blackberry (Malik et al., 1991; Mohadjer et al., 2001; Naraguma et al., 1999) and raspberry using soil-applied (Rempel et al., 2004; Strik et al., 2006) and foliarapplied (Reickenberg and Pritts, 1996) ${ }^{15} \mathrm{~N}$.

Plant $\mathrm{N}$ requirements depend on the time of year and with $\mathrm{N}$ partitioning within the plant, and thus vary throughout the growing season. Early in the season, summer-bearing blackberry and raspberry plants preferentially partitioned fertilizer $\mathrm{N}$ to new growth such as primocanes and fruit. At the end of the growing season, the fertilizer $\mathrm{N}$ was stored in roots, crown, and over-wintering primocanes (Malik et al., 1991; Mohadjer et al., 2001; Naraguma et al., 1999; Rempel et al., 2004). Little of the $\mathrm{N}$ stored in the overwintering primocanes (which become floricanes) was remobilized and used for new primocane growth in the spring. Thus, primocane growth is more dependent on new fertilizer $\mathrm{N}$ (Malik et al., 1991; Mohadjer et al., 2001; Naraguma et al., 1999; Rempel et al., 2004).

In an alternate year production system (Strik and Finn, 2012) of 'Kotata' trailing blackberry, Mohadjer et al. (2001) found that very little stored $\mathrm{N}$ was allocated to the primocanes of "on-year" plants (i.e., fruiting plants with both primocanes and floricanes). When ${ }^{15} \mathrm{~N}$ was applied in the "off-year" (primocanes only), 20\% of the $\mathrm{N}$ derived from the fertilizer was found within the fruit in the following "on-year," suggesting that reserves accumulated in the "off-year" are an important source for "on-year" growth. In the "on-year," $\mathrm{N}$ stored in the crown and root tissues was remobilized to fruiting laterals and fruit. They concluded that $\mathrm{N}$ fertilizer is needed in both the "on-year," for fruiting lateral and fruit growth, and in the "off-year," for new primocane growth.

Rempel et al. (2004) found that $\mathrm{N}$ derived from fertilizer declined by about $40 \%$ per year in biennialfruiting 'Meeker' red raspberry plants, indicating that plant $\mathrm{N}$ reserves were a very important $\mathrm{N}$ source in the crop. The amount of $\mathrm{N}$ used from the reserves, in this case, was much higher than the $10 \%$ reported by Dean et al. (2000) but similar to what was reported for trailing blackberry by Mohadjer et al. (2001). Malik et al. (1991) reported a decline of $73 \%$ of stored $\mathrm{N}$, but this was likely much higher than usual because no additional fertilizer $\mathrm{N}$ was applied in the second year of their study. Much of the decline in stored fertilizer $\mathrm{N}$ throughout the season was attributed to removal through fruit harvest, floricane pruning after senescence, and primocane leaf senescence.

Fertilizer $\mathrm{N}$ recovery, as a percentage of the ${ }^{15} \mathrm{~N}$ added, was $32 \%$ to $45 \%$ in blackberry (Mohadjer et al., 2001; Naraguma et al., 1999) and $24 \%$ to $37 \%$ in red raspberry, depending on the timing of fertilizer application (Rempel et al., 2004). However, the amount of fertilizer $\mathrm{N}$ reported as recovered might not provide a complete picture of overall $\mathrm{N}$ use in the plant. Fertilizer $\mathrm{N}$ uptake may impact the uptake and use of other forms of plant-available $\mathrm{N}$, such as storage and soil N (Bañados et al., 2012).

In summer-bearing red raspberry, fertilizer $\mathrm{N}$ applied early (before new primocane emergence or when primocanes were $<6$ inches tall) was taken up by the new primocanes and the fruiting laterals and fruit on the floricanes (Rempel et al., 2004). However, when fertilizer $\mathrm{N}$ was applied later (when green fruit were present at about 1 month before harvest), most of the fertilizer $\mathrm{N}$ was taken up by the primocanes, and very little of it went to the fruit. Research has suggested that a split application of granular fertilizer $\mathrm{N}$ (first half about 1 week before primocane emergence and the second half about 1 month before first harvest) is best for maintaining current season yield and good primocane growth for next season's yield (Rempel et al., 2004). Recently, we also investigated the potential of applying $\mathrm{N}$ to red raspberry by fertigation (D.R. Bryla and B.C. Strik, unpublished data). After 2 years, we found little difference in yield and leaf $\mathrm{N}$ concentrations when mature 'Meeker' plants were fertilized with split applications of granular $\mathrm{N}$ fertilizer or fertigated every 2 weeks from April to July with liquid sources of $\mathrm{N}$. In both cases, the plants were fertilized with a total of $70 \mathrm{lb} /$ acre $\mathrm{N}$ per year and had more growth and yield than plants grown for the same period without $\mathrm{N}$. Most nutrient management guides available to caneberry growers recommend split application of granular fertilizer or fertigation with liquid $\mathrm{N}$ fertilizer from spring through harvest (Bolda et al., 2012; Bushway et al., 2008; Hart et al., 2006; Krewer et al., 1999). In Washington, many raspberry growers using drip will use a combination of the two recommendations and apply a single application of $\mathrm{N}$ fertilizer in April (when it typically rains every week), and then, once irrigation is needed (usually by early to mid-May), apply the remaining $\mathrm{N}$ by fertigation (D.R. Bryla, personal observations).

\section{Accumulation and loss of nutrients}

Knowledge of annual accumulation of nutrients and periods of rapid uptake allows for better management of fertilization programs. Raspberry and blackberry have relatively low dry weight and $\mathrm{N}$ accumulation per acre compared with other perennial crops, due in part to the wide spacing between the rows (generally $10 \mathrm{ft}$ ), as well as small plant size and low yield (Dean et al., 2000; Mohadjer et al., 2001; Rempel et al., 2004; Strik, 2008).

Annual total $\mathrm{N}$ accumulation in the aboveground plant ranged from 62 to $109 \mathrm{lb} /$ acre in fieldgrown, summer-bearing red raspberry 
(Kowalenko, 1994b; Rempel et al., 2004; Wright and Waister, 1980) and 33 to $39 \mathrm{lb} /$ acre in field-grown blackberry (Mohadjer et al., 2001).

Plants receiving higher rates of $\mathrm{N}$ fertilizer took up more $\mathrm{N}$, often leading to higher $\mathrm{N}$ concentration in the tissues (e.g., Rempel et al., 2004). The $\mathrm{N}$ concentration of ripe fruit of fertilized plants ranged from $1.4 \%$ to $1.7 \%$ in red raspberry (Rempel et al., 2004 ), $1.4 \%$ to $1.6 \%$ in 'Kotata' trailing blackberry (Mohadjer et al., 2001 ), $1.5 \%$ to $1.6 \%$ in 'Arapaho' erect blackberry (Alleyne and Clark, 1997 ), and $0.9 \%$ to $1.1 \%$ in 'Black Diamond' and 'Marion' trailing blackberry (Harkins et al., 2014), with higher rates of $\mathrm{N}$ fertilization increasing fruit $\mathrm{N}$ concentration (Rempel et al., 2004). Nitrogen concentration declined in floricanes in the early spring, in fruiting laterals in spring through harvest and senescence, and in the fruit as it changed from green to ripe (Figs. 1 and 2). The $\mathrm{N}$ concentration of primocanes (Figs. 1 and 2) and primocane leaves (Fig. 1) declined throughout the season, particularly in early spring.

Fertilization with varying rates of $\mathrm{N}$ may affect the concentration of other nutrients not only in leaves, as described previously, but also in other plant parts (D.R. Bryla and B.C. Strik, unpublished data). The accumulation of macro- and micronutrients in 'Meeker' red raspberry usually preceded growth. Nutrient accumulation occurred very early in the season in floricanes (primarily in the fruiting laterals) and later in the season in primocanes. Likewise, crown and root nutrient content usually declined with dry matter during spring floricane production, and increased after fall leaf senescence. Primocanes generally contained the highest concentration of most nutrients during the growing season, except $\mathrm{Ca}, \mathrm{Cu}$, and $\mathrm{Zn}$, which often were more concentrated in roots. The roots typically contained the highest concentration of all nutrients during winter dormancy, indicating the storage of all nutrients [in addition to $\mathrm{N}$ (Rempel et al., 2004)] in roots, crowns, and primocanes is important for rapid lateral and fruit growth during the following spring (D.R. Bryla and B.C. Strik, unpublished data). Nutrient partitioning varied considerably among elements due to different

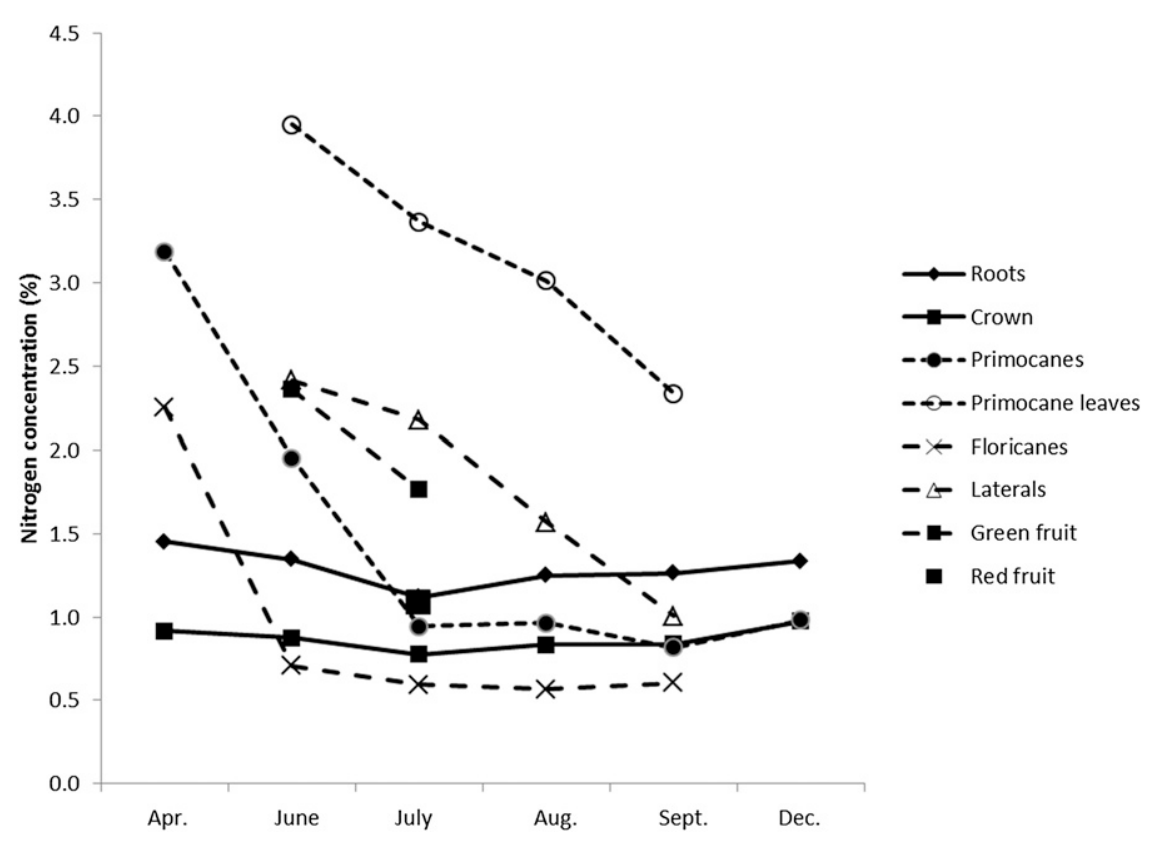

Fig. 1. Concentration of nitrogen in summer-bearing 'Meeker' red raspberry. The data are from Rempel et al. (2004) and averaged over two growing seasons.

nutrient concentrations and requirements in each plant part. This difference not only affected the proportion of each nutrient allocated to plant parts, but also the relative amount of each nutrient lost or removed during harvest, senescence, and pruning.

Floricane removal or pruning in a commercial caneberry field typically occurs any time after harvest throughout the fall. Rempel et al. (2004) found that if the floricanes of 'Meeker' red raspberry were pruned in mid-September rather than in midAugust, plant recovery of $\mathrm{N}$ from senescing floricanes increased by 5.5 $\mathrm{lb} /$ acre (Table 1 ). A similar difference in $\mathrm{N}$ recovery was found in 'Kotata' trailing blackberry (Mohadjer et al., 2001). Delaying pruning as long as possible, thus, allows greater time for floricane $\mathrm{N}$ to be remobilized to storage tissues. Strik et al. (2006) also found that when prunings were flail mowed and left in the field, the prunings returned $\mathrm{N}$ to the plant within 1.5 years, almost as efficiently as applying inorganic fertilizer.

If prunings and senesced leaves remain in the caneberry field, the only plant part removed from the field is the fruit. Trailing blackberry cultivars were reported to contain about $2.9 \mathrm{lb}$ $\mathrm{N}$ in each ton of fruit (Table 2), which is equivalent to $17.4 \mathrm{lb} /$ acre $\mathrm{N}$ for a typical-harvested yield of 6 tons/ acre. 'Meeker' red raspberry contained $3.5 \mathrm{lb} /$ ton $\mathrm{N}$ in fruit (Table 2 ), or $12.6 \mathrm{lb} /$ acre $\mathrm{N}$ for the reported machine-harvested yield of 3.5 tons/ acre (Rempel et al., 2004). The concentration of $\mathrm{Ca}, \mathrm{Mg}$, sulfur (S), B, and $\mathrm{Zn}$ in fruit differed among trailing blackberry cultivars (Table 2 ), and fruit $\mathrm{Ca}$ concentration was affected by weed management treatment (Harkins et al., 2014).

In trailing blackberry, nutrient loss in fruit and floricanes averaged 30 to $70 \mathrm{lb} /$ acre $\mathrm{N}, 4$ to $11 \mathrm{lb} /$ acre $\mathrm{P}$, 32 to $75 \mathrm{lb} /$ acre K, 21 to $54 \mathrm{lb} /$ acre $\mathrm{Ca}, 4$ to $13 \mathrm{lb} /$ acre $\mathrm{Mg}, 2$ to $4 \mathrm{lb} /$ acre $S, 5$ to $12 \mathrm{oz} /$ acre iron $(\mathrm{Fe}), 1$ to $4 \mathrm{oz} /$ acre B, 0.2 to $0.5 \mathrm{oz} /$ acre $\mathrm{Cu}, 9$ to $19 \mathrm{oz} /$ acre manganese $(\mathrm{Mn}), 0.1$ to $4 \mathrm{oz} /$ acre $\mathrm{Zn}$, and 6 to $14 \mathrm{oz} /$ acre aluminum $(\mathrm{Al})$, but varied among cultivars (Harkins et al., 2014).

In red raspberry, fruit harvest removed $2 \%$ to $27 \%$ of the plant's total nutrients (depending on the nutrient), while floricane pruning after harvest ("caning out") and leaf senescence removed $27 \%$ to $71 \%$ (D.R. Bryla and B.C. Strik, unpublished data). All together, these losses averaged an annual total of $33 \mathrm{lb} /$ acre $\mathrm{N}$, $3 \mathrm{lb} /$ acre $\mathrm{P}, 2 \mathrm{llb} /$ acre K, $19 \mathrm{lb} /$ acre $\mathrm{Ca}, 6 \mathrm{lb} /$ acre $\mathrm{Mg}, 2 \mathrm{lb} /$ acre S, 2.3 $\mathrm{oz} /$ acre $\mathrm{B}, 0.4 \mathrm{oz} / \mathrm{acre} \mathrm{Cu}, 3.6 \mathrm{oz} /$ acre $\mathrm{Mn}$, and $51.7 \mathrm{oz} /$ acre $\mathrm{Zn}$. Pruning early in mid-August removed an additional $1 \%$ to $19 \%$ of each nutrient 
(D.R. Bryla and B.C. Strik, unpublished data).

In addition to $\mathrm{N}$, the other nutrient removed to a large extent
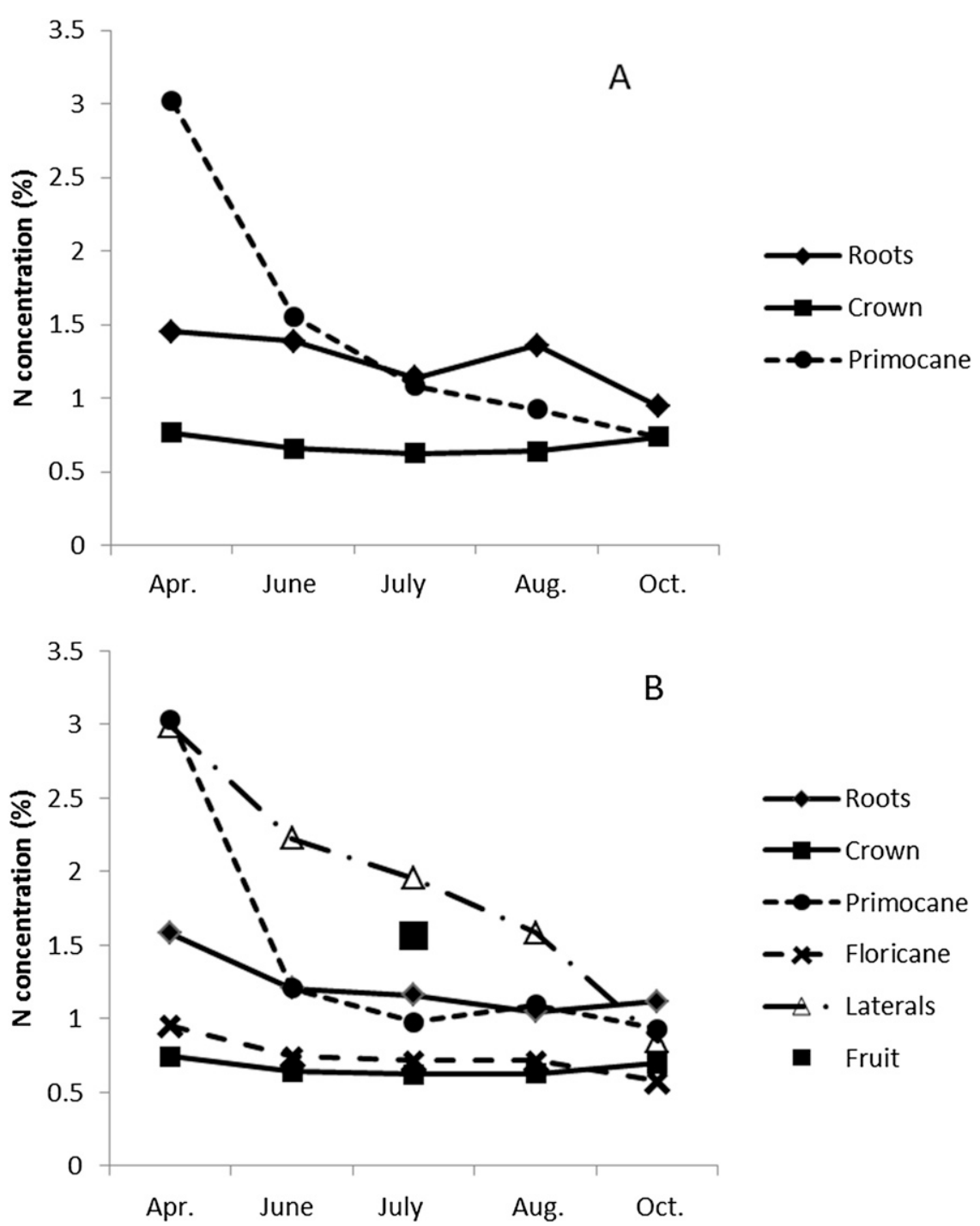

Fig. 2. Concentration of nitrogen $(\mathrm{N})$ in 'Kotata' trailing blackberry when sampled through the non-fruiting [A ("off-year)] and fruiting [B ("on-year")] season of an alternate-year production system. Adapted from Mohadjer et al. (2001). soil test for $\mathrm{K}$ is $<350 \mathrm{ppm}$ (Hart et al., 2006). The loss of $\mathrm{K}$ documented in caneberries supports the fertilizer guide recommendation (D.R. Bryla and B.C. Strik, unpublished data; Harkins et al., 2014).

Overall, raspberry and blackberry lose a significant portion of their total nutrients each season due to cultural activities and plant senescence. Of the nutrients usually applied to red raspberry, we estimate that 'Meeker' requires about $35 \mathrm{lb} /$ acre $\mathrm{N}, 3.5 \mathrm{lb} /$ acre $\mathrm{P}, 22 \mathrm{lb} /$ acre K, and $2.3 \mathrm{oz} / \mathrm{acre}$ $B$ each year for sustainable production in Oregon, where annual yield (fresh weight) is typically around 3.6 tons/ acre when machine harvested. In trailing blackberry, we estimate that $\approx 50$ $\mathrm{lb} /$ acre $\mathrm{N}, 8 \mathrm{lb} /$ acre $\mathrm{P}, 55 \mathrm{lb} / \mathrm{acre} \mathrm{K}$, and $\mathrm{l} \mathrm{oz} / \mathrm{acre} \mathrm{B}$ each year, where the annual yield (fresh weight) with machine harvest is typically around 6 tons/acre. These rates should be adjusted accordingly in more productive regions (e.g., northwestern Washington, CA). In addition, fertilizeruptake efficiency should be considered, as this varies with the application method and/or the product used. Any requirements for other nutrients are probably met by processes such as soil liming and application of pesticides and fungicides, soil weathering, and rainfall. Therefore, application of these other nutrients is only recommended when deficiency symptoms are noted through visual symptoms or measurement of leaf nutrient status.

\section{Leaf nutrient concentrations}

Primocane leaf nutrient status, as compared with published sufficiency

Table 1. Removal of nutrients in summer-bearing 'Meeker' red raspberry and 'Black Diamond' and 'Marion' trailing blackberry from pruning of senescent floricanes in August or September (raspberry) or mid-August (blackberry), and for leaf senescence on primocanes in autumn (raspberry only). Adapted from Rempel et al. (2004) and Harkins et al. (2014).

\begin{tabular}{|c|c|c|c|c|c|c|c|c|c|c|c|}
\hline \multirow[b]{2}{*}{ Crop and activity } & \multicolumn{6}{|c|}{ Macronutrients (lb/acre $)^{\mathrm{z}}$} & \multicolumn{5}{|c|}{ Micronutrients $(\mathrm{oz} / \mathrm{acre})^{\mathrm{z}}$} \\
\hline & $\mathbf{N}$ & $\mathbf{P}$ & $\mathbf{K}$ & $\mathrm{Ca}$ & $\mathrm{Mg}$ & $S$ & B & $\mathbf{C u}$ & Mn & $\mathrm{Zn}$ & $\mathrm{Fe}$ \\
\hline \multicolumn{12}{|c|}{ Summer-bearing raspberry } \\
\hline August & 17.3 & 1.2 & 9.4 & 15.3 & 3.1 & 0.9 & 1.7 & 0.2 & 2.1 & 0.5 & - \\
\hline September & 11.8 & 0.9 & 6.5 & 12.7 & 2.4 & 0.8 & 1.0 & 0.2 & 2.1 & 0.4 & 一 \\
\hline Leaf senescence & 9.5 & 0.7 & 4.2 & 5.0 & 2.1 & 0.4 & 0.8 & 0.1 & 1.2 & 0.1 & - \\
\hline 'Black Diamond' & 27.4 & 4.2 & 35.8 & 25.4 & 4.2 & 1.8 & 0.1 & 0.02 & 1.1 & 0.2 & 0.7 \\
\hline 'Marion' & 35.7 & 4.8 & 36.8 & 35.1 & 7.7 & 2.4 & 0.3 & 0.02 & 1.3 & 0.2 & 0.9 \\
\hline
\end{tabular}

${ }^{\mathrm{z}} \mathrm{l} \mathrm{lb} /$ acre $=1.1209 \mathrm{~kg} \cdot \mathrm{ha}^{-1}, \mathrm{l} \mathrm{oz} / \mathrm{acre}=70.0532 \mathrm{~g} \cdot \mathrm{ha}^{-1}, \mathrm{~N}=$ nitrogen, $\mathrm{P}=$ phosphorus, $\mathrm{K}=$ potassium, $\mathrm{Ca}=\mathrm{calcium}, \mathrm{Mg}=\mathrm{magnesium}, \mathrm{S}=$ sulfur, $\mathrm{B}=$ boron, Cu $=\mathrm{copper}, \mathrm{Mn}=$ manganese, $\mathrm{Zn}=$ zinc, $\mathrm{Fe}=$ iron. 
Table 2. Removal of nutrients per ton (fresh weight) of harvested fruit in summer-bearing 'Meeker' red raspberry and 'Black Diamond' and 'Marion' trailing blackberry. Adapted from Rempel et al. (2004) and Harkins et al. (2014).

\begin{tabular}{|c|c|c|c|c|c|c|c|c|c|c|c|c|}
\hline \multirow[b]{2}{*}{ Crop } & \multicolumn{6}{|c|}{ Macronutrients $(\mathrm{lb} / \text { ton })^{\mathrm{z}}$} & \multicolumn{6}{|c|}{ Micronutrients $(\mathrm{oz} / \text { ton })^{\mathrm{z}}$} \\
\hline & $\mathbf{N}$ & $\mathbf{P}$ & $\mathrm{K}$ & $\mathrm{Ca}$ & $\mathrm{Mg}$ & $S$ & B & $\mathrm{Cu}$ & Mn & $\mathrm{Zn}$ & $\mathrm{Fe}$ & Al \\
\hline Summer-bearing raspberry & 3.49 & 0.47 & 3.04 & 0.32 & 0.37 & 0.17 & 0.15 & 0.03 & 0.11 & 0.07 & - & - \\
\hline 'Black Diamond' & 2.89 & 0.53 & 3.01 & 0.45 & 0.27 & 0.20 & 0.05 & 0.02 & 0.19 & 0.06 & 0.15 & 0.40 \\
\hline 'Marion' & 2.87 & 0.63 & 3.02 & 0.73 & 0.37 & 0.19 & 0.05 & 0.03 & 0.23 & 0.08 & 0.19 & 0.43 \\
\hline
\end{tabular}

${ }^{\mathrm{z}} \mathrm{l} \mathrm{lb} /$ ton $=0.5000 \mathrm{~kg} \cdot \mathrm{Mg}^{-1}, \mathrm{l} \mathrm{oz} /$ ton $=31.2500 \mathrm{~g} \cdot \mathrm{Mg}^{-1}, \mathrm{~N}=$ nitrogen, $\mathrm{P}=$ phosphorus, $\mathrm{K}=$ potassium $, \mathrm{Ca}=\mathrm{calcium}, \mathrm{Mg}=\mathrm{magnesium}, \mathrm{S}=\mathrm{sulfur}, \mathrm{B}=\mathrm{boron}, \mathrm{Cu}=\mathrm{copper}$, $\mathrm{Mn}=$ manganese, $\mathrm{Zn}=$ zinc, $\mathrm{Fe}=$ iron, $\mathrm{Al}=$ aluminum.

Table 3. Recommended primocane leaf nutrient sufficiency levels for raspberry and blackberry when sampled in late-July to early-August in Oregon, May to August in California, and the first week of August in northeastern United States. In Oregon, the recommendations are to use whole leaves (petioles included) and to leave them unwashed. In California, there are no specifications for leaf petioles or washing. In the northeast, recommendations include petiole removal and leaf washing.

\begin{tabular}{lccc}
\hline Nutrient & Oregon $^{\mathrm{z}}$ & California $^{\mathrm{y}}$ & Northeastern United States $^{\mathrm{x}}$ \\
\hline Nitrogen (\%) & $2.3-3.0$ & $2.0-3.0$ & $2.0-3.0$ \\
Phosphorus (\%) & $0.19-0.45$ & $0.25-0.40$ & $0.25-0.40$ \\
Potassium (\%) & $1.3-2.0$ & $1.5-2.5$ & $1.5-2.5$ \\
Calcium (\%) & $0.6-2.0$ & $0.6-2.5$ & $0.6-2.0$ \\
Magnesium (\%) & $0.3-0.6$ & $0.3-0.9$ & $0.6-0.9$ \\
Sulfur (\%) & $0.1-0.2$ & - & $0.4-0.6$ \\
Manganese (ppm) & $50-300$ & $50-200$ & $50-200$ \\
Boron $(\mathrm{ppm})$ & $30-70$ & $30-50$ & $30-70$ \\
Iron (ppm) & $60-250$ & $50-200$ & $60-250$ \\
Zinc (ppm) & $15-50$ & $20-50$ & $20-50$ \\
Copper $(\mathrm{ppm})$ & $6-20$ & $7-50$ & $6-20$
\end{tabular}

${ }^{\mathrm{z}}$ Hart et al. (2006).

'Bolda et al. (2012).

${ }^{x}$ Bushway et al. (2008)

${ }^{\mathrm{w}} \mathrm{l} \mathrm{ppm}=\mathrm{l} \mathrm{mg} \cdot \mathrm{kg}^{-1}$

levels (Bolda et al., 2012; Bushway et al., 2008; Hart et al., 2006), coupled with observations of plant growth and yield are presently used to develop nutrient management programs in all caneberry types. In floricane-fruiting blackberry and raspberry, leaf sampling of primocanes in mid to late season informs growers of plant nutrient requirements for fruit production the following season. Leaf sampling is recommended for primocanes from May to August (Bolda et al., 2012), "following harvest" (Fernandez and Ballington, 1999), the first week of August (Bushway et al., 2008), or late July to early August (Hart et al., 2006), regardless of type of caneberry crop or the fruiting season of the cultivar. The recommended nutrient sufficiency levels are similar among these currently available nutrient management guides and all have the same standards, regardless of caneberry type and sampling method [e.g., using whole leaves (petioles included) and washing before analysis (Table 3)]. However, no standards have been published specifically for primocane-fruiting types of in their growth and development relative to floricane-fruiting types.

Primocane leaf nutrient levels have been shown to vary over the growing season in floricane-fruiting blackberry (Clark et al., 1988; Mohadjer et al., 2001; B.C. Strik and A. Vance, unpublished data), floricanefruiting raspberry (D.R. Bryla and B.C. Strik, unpublished data; Hughes et al., 1979; John and Daubeny, 1972; John et al., 1976; Kowalenko, 1981, 1994a; Wright and Waister, 1980), primocanefruiting raspberry (D.R. Bryla and B.C. Strik, unpublished data) and primocanefruiting blackberry (Strik, 2015). In Oregon, late July to early August appears to be an acceptable date for sampling primocane leaves for plant nutrient assessment of primocaneand floricane-fruiting raspberry (D.R. Bryla and B.C. Strik, unpublished data) and floricane-fruiting blackberry (trailing, erect, and semierect; B.C. Strik and raspberry or blackberry, which differ
A. Vance, unpublished data) cultivars, but not for primocane-fruiting blackberry, where sampling leaves on primocane branches during the green fruit stage is recommended (Strik, 2015).

Presently published leaf tissue sufficiency levels (Table 3) appear to be too high for $K$ in primocanefruiting raspberry (D.R. Bryla and B.C. Strik, unpublished data) and blackberry (Strik, 2015), which is not surprising considering primocane leaves sampled at this time are from canes that are also producing fruitfruit are a considerable sink for $\mathrm{K}$ (Table 2). Strik (2015) also suggested lowering the sufficiency level for $\mathrm{P}$ in primocane-fruiting blackberry to discourage application of fertilizer $\mathrm{P}$ when it is not required.

Current recommendations are to sample cultivars separately for tissue analysis (e.g., Hart et al., 2006), which has been confirmed by finding cultivar differences among primocane leaf nutrients in floricane-fruiting blackberry (Fernandez-Salvador et al., 2015a, 2015b, 2015c; Harkins et al., 2014; B.C. Strik and A. Vance, unpublished data) and raspberry (John and Daubeny, 1972; John et al., 1976) and primocane-fruiting raspberry (D.R. Bryla and B.C. Strik, unpublished data) and blackberry (Strik, 2015). In contrast, Clark et al. (1988) found no difference among three erect blackberry cultivars in leaf nutrient levels and speculated that this was due to their similar parentage.

\section{Conclusions}

Growers typically base $\mathrm{N}$ fertilization decisions on results of tissue analysis of primocane leaves taken in late July to early August (northern hemisphere), soil tests every few years, and observations of annual growth (cane number, diameter, and height, and fruiting lateral length), yield, color of leaves, and fruit quality (amount of rot and drupelet set). 
Research on $\mathrm{N}$ uptake (using ${ }^{15} \mathrm{~N}$ ) has shown that caneberry plants require fertilizer $\mathrm{N}$ in early spring for primocane growth and for growth of floricanes (fruiting laterals and fruit). Stored N is remobilized from roots, crown, and over-wintering primocanes for growth of fruiting laterals and fruit. Nutrients are also remobilized from senescing floricanes, offering an advantage when pruning is delayed. Peak accumulation of other nutrients primarily occurs immediately before maximum growth. Annual fertilization with $\mathrm{N}, \mathrm{P}, \mathrm{K}$, and $\mathrm{B}$ is recommended to replace the nutrients lost with fruit harvest and pruning, considering nutrient source and fertilizer-uptake efficiency. Monitoring plant growth and plant nutrient status are recommended to adjust nutrient programs.

\section{Literature cited}

Alleyne, V. and J.R. Clark. 1997. Fruit composition of 'Arapaho' blackberry following nitrogen fertilization. HortScience 32:282-283.

Archbold, D.D., J.G. Strang, and D.M. Hines. 1989. Yield component responses of 'Hull Thornless' blackberry to nitrogen and mulch. HortScience 24:604-607.

Bañados, M.P., B.C. Strik, D.R. Bryla, and T.L. Righetti. 2012. Response of highbush blueberry to nitrogen fertilizer during field establishment. I. Accumulation and allocation of fertilizer nitrogen and biomass. HortScience 47:648-655.

Bolda, M., M. Gaskell, E. Mitcham, and M. Cahn. 2012. Fresh market caneberry production manual. Univ. California Agr. Natural Resources Publ. 3525.

Bushway, L., M. Pritts, and D. Handley (eds.). 2008. Raspberry \& blackberry production guide for the northeast, midwest, and eastern Canada. Plant Life Sci. Publ. Coop. Ext. NRAES-35.

Buskiene, L. and N. Uselis. 2008. The influence of nitrogen and potassium fertilizers on the growth and yield of raspberries cv. 'Polana'. Agron. Res 6:27-35.

Chaplin, M.H. and L.W. Martin. 1980. The effect of nitrogen and boron fertilizer applications on leaf levels, yield and fruit size of the red raspberry. Commun. Soil Sci. Plant Anal. 11:547-556.

Clark, J.R., J.B. Buckley, III., and E.W. Hellman. 1988. Seasonal variation in elemental concentration of blackberry leaves. HortScience 23:1080 (abstr.).
Claussen, W. and F. Lenz. 1999. Effect of ammonium or nitrate nutrition on net photosynthesis, growth, and activity of the enzymes nitrate reductase and glutamine synthetase in blueberry, raspberry and strawberry. Plant Soil 208:95-102.

Dale, A. 1989. Productivity in red raspberries. Hort. Rev. 11:185-228.

Dean, D.M., B.J. Zebarth, C.G. Kowalenko, J.W. Paul, and K. Chipperfield. 2000. Poultry manure effects on soil nitrogen processes and nitrogen accumulation in red raspberry. Can. J. Plant Sci. 80:849-860.

DeGomez, T.E., L.W. Martin, and P.J. Breen. 1986. Effect of nitrogen and pruning on primocane fruiting red raspberry 'Amity'. HortScience 21:441-442.

Fernandez, G. and J. Ballington. 1999. Growing blackberries in North Carolina. North Carolina State Univ. Ext. Serv. Publ. AG-401.

Fernandez-Salvador, J., B.C. Strik, and D.R. Bryla. 2015a. Liquid corn and fish fertilizers are good options for fertigation in blackberry cultivars grown in an organic production system. HortScience 50:225-233.

Fernandez-Salvador, J., B.C. Strik, and D.R. Bryla. 2015b. Response of blackberry cultivars to fertilizer source during establishment in an organic fresh market production system. HortTechnology 25:277-292.

Fernandez-Salvador, J., B.C. Strik, Y. Zhao, and C.E. Finn. 2015c. Trailing blackberry genotypes differ in yield and postharvest fruit quality during establishment in an organic production system. HortScience 50:240-246.

Gale, E.S., D.M. Sullivan, C.G. Cogger, A.I. Bary, D.D. Hemphill, and E.A. Myhre. 2006. Estimating plant-available nitrogen release from manures, composts, and specialty products. J. Environ. Qual. 35:2321-2332.

Gutser, R., T. Ebertseder, A. Weber, M. Schraml, and U. Schmidhalter. 2005 Short-term and residual availability of nitrogen after long-term application of organic fertilizers on arable land. J. Plant Nutr. Soil Sci. 168:439-445.

Harkins, R.H., B.C. Strik, and D.R. Bryla. 2014. Weed management practices for organic production of trailing blackberry: II. Accumulation and loss of biomass and nutrients. HortScience 49:35-43.

Hart, J., B.C. Strik, and H. Rempel. 2006. Caneberries. Nutrient management guide. Oregon State Univ. Ext. Serv. EM8903-E.

Heiberg, N. 2002. Effect of vegetation control and nitrogen fertilization in red raspberry. Acta Hort. 585:579-583.
Hughes, M., M.H. Chaplin, and A.R. Dixon. 1979. Elemental composition of red raspberry leaves as a function of time of season and position on cane. HortScience 14:46-47.

John, M.K. and H.A. Daubeny. 1972. Influence of genotype, date of sampling, and age of plant on leaf chemical composition of red raspberry (Rubus idaeus L.). J. Amer. Soc. Hort. Sci. 97:740-742.

John, M.K., H.A. Daubeny, and H.H. Chuah. 1976. Factors affecting elemental composition of red raspberry leaves. J. Sci. Food Agr. 27:877-882.

Kowalenko, C.G. 1981. The effect of nitrogen and boron soil applications on raspberry leaf $\mathrm{N}, \mathrm{B}$ and $\mathrm{Mn}$ concentrations and on selected soil analyses. Commun. Soil Sci. Plant Anal. 12:1163-1179.

Kowalenko, C.G. 1994a. Growing season changes in the concentration and distribution of macroelements in Willamette red raspberry plant parts. Can. J. Plant Sci. 74:833-839.

Kowalenko, C.G. 1994b. Growing season dry matter and macroelement accumulations in 'Willamette' red raspberry and related soilextractable macroelement measurements. Can. J. Plant Sci. 74:565-571.

Kowalenko, C.G., J.C.W. Keng, and J.A. Freeman. 2000. Comparison of nitrogen application via a trickle irrigation system with surface banding of granular fertilizer on red raspberry. Can. J. Plant Sci. $80: 363-371$.

Krewer, G., B. Smith, P. Brannen, and D. Horton. 1999. Commercial bramble culture. Coop. Ext. Serv. Univ. Georgia Bul. 964.

Kuepper, G.L., H. Born, and J. Bachmann. 2003. Organic culture of bramble fruits. Horticultural production guide. Appropriate Technol. Transfer Rural Areas IPO22.

Larco, H., B.C. Strik, D.R. Bryla, and D. M. Sullivan. 2013. Mulch and fertilizer management practices for organic production of highbush blueberry: II. Impact on plant and soil nutrients during establishment. HortScience 48:1484-1495.

Lawson, H.M. and P.D. Waister. 1972. The response to nitrogen of a raspberry plantation under contrasting systems of management for a weed and sucker control. Hort. Res. 12:43-55.

Lockshin, L.S. and D.C. Elfving. 1981. Flowering response of 'Heritage' red raspberry to temperature and nitrogen. HortScience 16:527-528.

Malik, H., D. Archbold, and C.T. Mackown. 1991. Nitrogen partitioning by 'Chester Thornless' blackberry in pot culture. HortScience 26:1492-1494. 
Mohadjer, P., B.C. Strik, B.J. Zebarth, and T.L. Righetti. 2001. Nitrogen uptake, partitioning and remobilization in 'Kotata' blackberries in alternate year production. J. Hortic. Sci. Biotechnol. 76:700-708.

Naraguma, J. and J.R. Clark. 1998. Effect of nitrogen fertilization on 'Arapaho' thornless blackberry. Commun. Soil Sci. Plant Anal. 29:2775-2783.

Naraguma, J., J.R. Clark, R.J. Norman, and R.W. McNew. 1999. Nitrogen uptake and allocation by field-grown 'Arapaho' thornless blackberry. J. Plant Nutr. 22:753-768.

Nelson, E. and L.W. Martin. 1986. The relationship of soil-applied $\mathrm{N}$ and $\mathrm{K}$ to yield and quality of 'Thornless Evergreen' blackberry. HortScience 21:1153-1154.

Papp, J., I. Kobzos-Pápai, and J. Nagy. 1984. Effect of nitrogen application on yield, leaf nutrient status and fruit chemical composition of raspberry and redcurrant varieties. Acta Agronomica Academiae Scientiarum Hungaricae 33:337-343.

Reickenberg, R.L. and M.P. Pritts. 1996. Dynamics of nutrient uptake from foliar fertilizers in red raspberry. J. Amer. Soc. Hort. Sci. 121:158-163.

Rempel, H., B. Strik, and T. Righetti. 2004. Uptake, partitioning and storage of fertilizer nitrogen in red raspberry as affected by rate and timing of application. J. Amer. Soc. Hort. Sci. 129:439-448.

Rincon, A.R. and J.A. Salas M. 1987. Influence of the levels of $\mathrm{N}, \mathrm{P}$, and $\mathrm{K}$ on the yield of blackberry. Acta Hort. 199:183-185.

Smolarz, K., T. Mercik, and S. Mercik. 1982. Growth and fruiting of raspberries on the plots with mineral fertilization diversified since 1923. Fruit Sci. Rpt. 9:159-170.

Spiers, J.M. 1993. Nitrogen, calcium, and magnesium fertilization affects growth and leaf elemental content of 'Dormanred' raspberry. J. Plant Nutr. $16: 2333-2339$.

Spiers, J.M. and J.H. Braswell. 2002. Influence of $\mathrm{N}, \mathrm{P}, \mathrm{K}, \mathrm{Ca}$, and $\mathrm{Mg}$ rates on leaf macronutrient concentration of 'Navaho' blackberry. Acta Hort. 585:659-663.

Strik, B.C. 2015. Seasonal variation in mineral nutrient content of primocanefruiting blackberry leaves. HortScience 50:540-545.

Strik, B.C. 2012. Flowering and fruiting on command in berry crops. Acta Hort. 926:197-214.

Strik, B. 2008. A review of nitrogen nutrition of Rubus. Acta Hort. 777:403410 .
Strik, B.C., J.R. Clark, C.E. Finn, and P. Bañados. 2007. Worldwide production of blackberries, 1995 to 2005 and predictions for growth. HortTechnology 17:205-213.

Strik, B.C. and C.E. Finn. 2012. Blackberry production systems: A worldwide perspective. Acta Hort. 946:341-348.

Strik, B., T. Righetti, and H. Rempel. 2006. Black plastic mulch improved the uptake of ${ }^{15} \mathrm{~N}$ from inorganic fertilizer and organic prunings in summer-bearing red raspberry. HortScience 41:272-274.

U.S. Department of Agriculture. 2010. 2007 Census of agriculture: Organic production survey (2008). 16 Feb. 2015. <http://www.agcensus.usda.gov/ Publications/2007/Online_Highlights/ Organics $/>$.

U.S. Department of Agriculture. 2015. Noncitrus fruits and nuts: 2014 Preliminary summary. Jan. 2015. 15 Feb. 2015. <http://www.nass.usda.gov/ Publications/Todays_Reports/reports/ ncit0115.pdf>.

Wright, C.J. and P.D. Waister. 1980. Seasonal changes in the mineral nutrient content of the raspberry. Acta Hort. 112:295-304. 